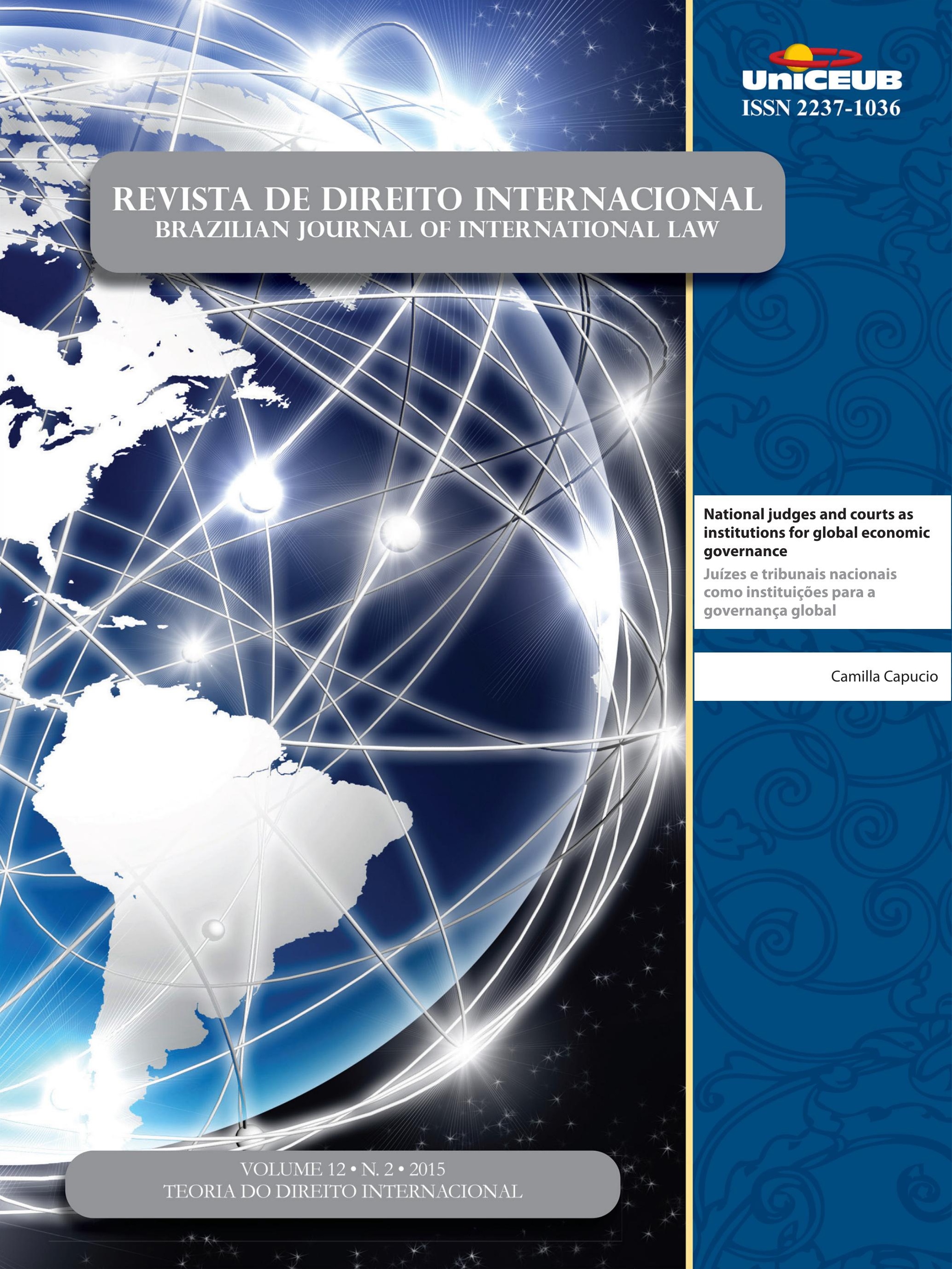




\section{Sumário}

CrôNiCAS DA ATUALIDADE do DiREITo INTERnACIONAL ..................................................... 2 Sarah Dayanna Lacerda Martins Lima, Carina Costa de Oliveira e Erika Braga

CrôniCas do Direito InternaCional dos InVESTIMENTOS ..............................................12 Nitish Monebhurrun

Por que voltar a Kelsen, o jurista do século XX ? 16 Inocêncio Mártires Coelho

O Princípio da Efetividade como conteúdo da norma fundamental (GrundNorm) DE KELSEN

Carlos Alberto Simões de Tomaz e Renata Mantovani de Lima

A JURIDIFICAÇÃo DE CONFLITOS POLÍTICOS NO DIREITO INTERNACIONAL PÚBLICO CONTEMPORÂ-

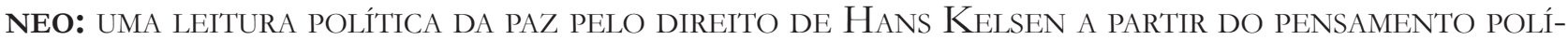
TICO De Claude Lefort

Arthur Roberto Capella Giannattasio

O SINCRETISMO TEÓRICO NA APROPRIAÇÃO DAS TEORIAS MONISTA E DUALISTA E SUA QUESTIONÁVEL UTILIDADE COMO CRITÉRIO PARA A CLASSIFICAÇÃO DO MODELO BRASILEIRO DE INCORPORA-

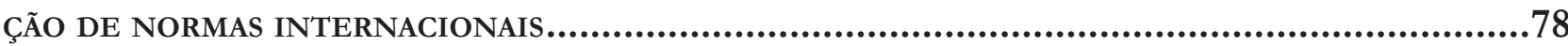
Breno Baía Magalhães

Direito Global em Pedaços: Fragmentação, Regimes e Pluralismo .98 Salem Hikmat Nasser

Por uma TeOria JURÍdica da INTEGRaÇão REgIONAL: A INTER-RELAÇÃO DiREITO INTERNO, DiREITO INTERNACIONAL PÚBLICO E DIREITO DA INTEGRAÇÃO Jamile Bergamaschine Mata Diz e Augusto Jaeger Júnior

A teOria DA INTERCONSTITUCIONALIDADE: UMA ANÁlISE COM BASE NA AMÉRICA LATINA...........160 Daniela Menengoti Ribeiro e Malu Romancini 
O DIÁLOGO HERMENÊUTICO E A PERGUNTA ADEQUADA À APLICAÇÃo DOS TRATADOS INTERNACIONAIS DE DIREITOS HUMANOS NO BRASIL: CAMINHOS PARA O PROCESSO DE INTERNACIONALIZAÇÃO

DA CONSTITUIÇÃO...................................................................................... 176

Rafael Fonseca Ferreira e Celine Barreto Anadon

O DIREITO COMPARADO NO STF: INTERNACIONALIZAÇÃO DA JURISDIÇÃO CONSTITUCIONAL BRASILEIRA

Carlos Bastide Horbach

THE PHILOSOPHY OF INTERNATIONAL LAW IN CONTEMPORARY SCHOLARSHIP: OVERCOMING NE-

GLIGENCE THROUGH THE GLOBAL EXPANSION OF HUMAN RIGHTS

Fabrício Bertini Pasquot Polido, Lucas Costa dos Anjos e Vinícius Machado Calixto

OpORTUNIDADES E DESAFIOS DAS TWAIL NO CONTEXTO LATINO-AMERICANO A PARTIR DE PERSPECTIVAS DOS POVOS INDÍGENAS AO DIREITO INTERNACIONAL

Fernanda Cristina de Oliveira Franco

Por Que uma ANÁlise ECONÔMICA Do DIREITO INTERNACIONAL PÚBLICO? DESAFIOS E PERSPECTIVAS DO MÉTODO NO BRASII

Gustavo Ferreira Ribeiro e Jose Guilherme Moreno Caiado

ANÁliSE ECONÔMICA do DIREITO INTERNACIONAL .263 Michele Alessandra Hastreiter e Luís Alexandre Carta Winter

RACIONALIDADE ECONÔMICA E OS ACORDOS BILATERAIS DE INVESTIMENTO 284 Michele Alessandra Hastreiter e Luís Alexandre Carta Winter

LOOKING FOR A BRICS PERSPECTIVE ON INTERNATIONAL LAW .304 Gabriel Webber Ziero

A INFLUÊNCIA DO DIREITO DESPORTIVO TRANSNACIONAL NO ORDENAMENTO JURÍDICO BRASILEIRO: DA REPRODUÇÃO DE NORMAS À APLICAÇÃO DIRETA PELA JURISDIÇÃO ESTATAL.......................3324 Tiago Silveira de Faria

CONVENCIONALIZAÇÃo DO DIREITO CIVIL: A APLICAÇÃo DOS TRATADOS E CONVENÇÕES INTERNACIONAIS NO ÂMBITO DAS RELAÇÕES PRIVADAS . 
NATIONAL JUdGES AND COURTS AS INSTITUTIONS FOR GLOBAL ECONOMIC GOVERNANCE 356

Juízes e tribunais nacionais como instituições para a governança global 356 Camilla Capucio

Is Trade Governance Changing? 371 Alberto do Amaral Júnior

OS FUNDOS ABUTRES: MEROS PARTICIPANTES DO CENÁRIO INTERNACIONAL OU SUJEITOS PERANTE O DIREITO INTERNACIONAL? 384

Guilherme Berger Schmitt

SHAREHOLDER AGREEMENTS IN PUBLICLY TRADED COMPANIES: A COMPARISON BETWEEN THE

U.S. AND BRAZIL. 402 Helena Masullo

REgulaÇÃo DO INVESTIMENTO ESTRANGEIRO DIRETO NO BRASIL: DA RESISTÊNCIA AOS TRATADOS BILATERAIS DE INVESTIMENTO À EMERGÊNCIA DE UM NOVO MODELO REGULATÓRIO 421 Fabio Morosini e Ely Caetano Xavier Júnior

DA QUALIFICAÇÃo JURÍDiCA dAS Distintas FORMAS DE PRESTAÇão TECNOLÓGICA: BREVE ANÁLISE DO MARCO REGULATÓRIO INTERNACIONAL

Daniel Amin Ferraz

REDEFINING TERRORISM: THE DANGER OF MISUNDERSTANDING THE MODERN WORLD'S GRAVEST THREAT

Jennifer Breedon

As EXECUÇões SELETIVAS E A RESPONSABILIZAÇÃo DE AGENTES TERRORISTAS 485 Alexandre Guerreiro

INTERNATIONAL CRIMINALS AND THEIR VIRTUAL CURRENCIES: THE NEED FOR AN INTERNATIONAL EFFORT IN REGULATING VIRTUAL CURRENCIES AND COMBATING CYBER CRIME Joy Marie Virga

Criminalidad transnacional organizada en el Ámbito del MERCOSUR: ¿Hacia un Derecho Penal Regional?. .528 Nicolás Santiago Cordini e Mariano Javier Hoet 
RUMO À INTERNACIONALIZAÇÃo DA PROTEÇÃO PENAL DO MEIO AMBIENTE: DOS ECOCRIMES AO ECOCÍDIO

Kathia Martin-Chenut, Laurent Neyret e Camila Perruso

Engaging the U.N. Guiding Principles on Business and Human Rights: the inter-AMERICAN COMMISSION ON HUMAN RIGHTS \& THE EXTRACTIVE SECTOR 571 Cindy S. Woods

O DIREITO HUMANO À COMUNICAÇÃo PRÉVIA E PORMENORIZADA DAS ACUSAÇÕES NOS PROCESSOS administrativos: O desprezo do Superior Tribunal de Justiça ao Pacto de San José da Costa Rica e À Corte Interamericana de Direitos Humanos .590

Daniel Wunder Hachem e Eloi Pethechust

A responsabilidade internacional do Brasil em FaCe do CONTRole de ConVENCionaliDADE EM SEDE DE DIREITOS HUMANOS: CONFLITO DE INTERPRETAÇÃO ENTRE A JURISDIÇÃO DA Corte Interamericana de Direitos Humanos e o Supremo Tribunal Federal quanto a LEI DE ANISTIA 612

Carla Ribeiro Volpini Silva e Bruno Wanderley Junior

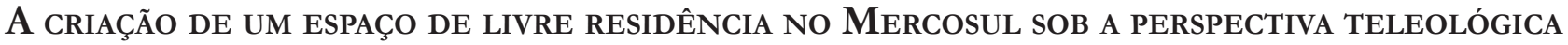
DA INTEGRAÇÃo REGIONAL: ASPECTOS NORMATIVOS E SOCIAIS DOS ACORDOS DE RESIDÊNCIA ....... 631

Aline Beltrame de Moura

A funcionalização como tendênCia evolutiva do Direito Internacional e sua conTRIBUIÇÃO AO REGIME LEGAL DO BANCO DE DADOS DE IDENTIFICAÇÃO DE PERFIL GENÉTICO NO BRASIL

Antonio Henrique Graciano Suxberger

O DIREITO INTERNACIONAL E A PROTEÇÃO DOS DIREITOS DE CRIANÇAS E DE ADOLESCENTES EM CONFLITO COM A LEI EM MOÇAMBIQUE

Bernardo Fernando Sicoche

ObTenÇão de PRovas no EXTERIOR: PARA ALÉM dA LEX FORI E LEX DiLigENTIAE. .685 André De Carvalho Ramos 
A Slight Revenge and a Growing Hope for Mauritius and the Chagossians: The UNClos Arbitral Tribunal's Award of 18 March 2015 on Chagos Marine Protected Area (Mauritius v. United Kingdom)

Géraldine Giraudeau

ANÁLISE DA RESPONSABILIDADE INTERNACIONAL DA UCRÂNIA POR VIOLAÇÃo DOS DIREITOS HUmanos na QUeda do voo da Malaysia Airlines (MH17). .728

Daniela Copetti Cravo

NatureZa JURÍdica do DESENVOLVIMENTO SUSTENTÁVEL No DIREITO INTERNACIONAL ........739 Pedro Ivo Diniz

A INFLUÊNCIA Da SOFT LAW NA FORMaÇão do DiREITo AMBIENTAL .767 Leonardo da Rocha de Souza e Margareth Anne Leister

As COMPLICADAS INTER-RELAÇÕES ENTRE OS SISTEMAS INTERNOS E INTERNACIONAIS DE PROTEÇãO DO DIREITO AO MEIO AMBIENTE SADIO. 785 José Adércio Leite Sampaio e Beatriz Souza Costa 


\title{
National judges and courts as institutions for global economic governance*
}

\author{
Juízes e tribunais nacionais como \\ instituições para a governança global
}

Camilla Capucio**

\begin{abstract}
This paper aims to explore the relationship between national judges and courts and the international economic order, from the perspective of global economic governance. It is proposed, therefore, the thesis that there is room and need for active participation of these bodies as institutions of global governance, through four sections. The first section presents concepts such as international order and global governance, guiding to the succeeding reflections. The second part enters into the question of disaggregation of State and its consequences in international trade relations. Third section deals with the perspective of constitutionalism and cosmopolitan law as a project for global order, and the layers of multilevel trade governance encompassing multilateral, regional and national levels of norms and institutions. Fourth part discusses the role of national courts, understood as having also an international authority, in international economic order. Fifth section focuses on the relation between national judiciary and the multilateral rules and WTO Dispute Settlement Mechanism decisions. This thesis explored in the paper is an attempt to overcome the perspective of classic international law that erects a wall of separation between international order and domestic order, in what consists its main value, as a new perspective for international law as a broader instrument for global governance.
\end{abstract}

Keywords: National Courts. Global Economic Governance. Multilevel Trade Governance. International Order. World Trade Organization. Dispute Settlement.

* Recebido em 21/09/2015

Aprovado em 02/11/2015

** Doutoranda pela Faculdade de Direito da Universidade de São Paulo -USP. Mestre em Direito pela Faculdade de Direito da Universidade Federal de Minas Gerais - UFMG, com experiência de estudos realizados na Universitá di Bologna - UNIBO. Ex-bolsista do CNPq. Advogada e Consultora Jurídica. Professora de Graduação em Direito no Centro Universitário UNA. Professora de cursos de Pós-Graduação latu senso (Escola Paulista de Direito e Faculdades Promove). Coordenadora da linha temática sobre o Mecanismo de Solução de Controvérsias da OMC, do Núcleo de Estudos em Tribunais Internacionais - NETI-USP. Email: ccapucio@usp.br.

\section{Resumo}

Este trabalho tem como objetivo explorar a relação entre os juízes e os tribunais nacionais e a ordem econômica internacional, a partir da perspectiva da governança econômica global. Propõe-se, portanto, a tese de que não apenas há espaço para, mas há necessidade de necessidade de participação ativa destes órgãos como instituições de governança global, por meio de cinco seções. A primeira seção apresenta conceitos como ordem internacional e governança global, orientando as reflexões seguintes. A segunda parte adentra na questão da desagregação do Estado e as suas consequências nas relações comerciais internacionais. A terceira seção trata da perspectiva do constitucionalismo e do direito cosmopolita como um projeto para a 
ordem global, e as camadas de governança em vários níveis para o comércio, abrangendo níveis multilaterais, regionais e nacionais de normas e instituições. A quarta parte discute o papel dos tribunais nacionais, entendidos como tendo também uma autoridade internacional, na ordem econômica internacional e a quinta seção, por fim, explora a relação entre o poder judiciário nacional e as decisões do Mecanismo de Solução de Controvérsias da OMC. Esta tese explorada no trabalho é uma tentativa de superar a perspectiva do Direito Internacional clássico, que ergue uma rígida separação entre a ordem internacional e ordem interna, no que consiste o seu valor principal, como uma nova perspectiva para o direito internacional como um instrumento mais amplo para a governança global.

Palavras-chave: Órgãos Jurisdicionais Nacionais. Governança Econômica Global. Governança Econômica De Vários Níveis. Ordem Internacional. Organização Mundial Do Comércio. Solução De Controvérsias.

\section{Order, International LaW and Global Governance: Reconstruction of Relevant CONCEPTS}

Aiming to initiate the discussion on the place for national judges and courts in global governance, and therefore in global economic governance, it is necessary to reflect about certain concepts, theoretical grounds upon which this paper is based. Initially, we must address the concept of order, and its relationship with International Law and global governance.

According to the conception of Redley Bull, order in a broad sense means the manner in which things related to each other, according to some pattern. Worth noting that order is not necessarily synonymous with law, and in this sense the author seeks to remove the normative element of the definition of order, though not disregarding its role in creating order. ${ }^{1}$ In this perspective, we take the vision of international order as " $a$

1 BULL, Hedley. The Anarchical Society: a study of order in world politics. 3. ed. Basingstoke; New York: Palgrave, 2002. p. 7. "I have sought deliberately to find a definition of order in social life that excludes the conception of rules. This is because, for reasons discussed in Chapter 3, I believe order in social life can exist in principle without rules, and that it is best to treat rules as a widespread, and nearly ubiquitous means of creating order in human society, rather than as part of the definition of order itself." pattern of activity that sustains the elementary or primary goals of the society of states, or international society" ${ }^{2}$ Therefore, international order is a pattern of social actions purposely oriented, to achieve primary objectives of the international society, a society of states which necessarily requires that states has common values and interests. ${ }^{3}$

To our objectives, the most important feature of BuLL's work lies in the differentiation between international society and world society, because it brings the necessity to consider rules, norms and institutions that lies beyond the state, and rethink about the management of change within international legal and normative structure of global order. In his conception, international society means a society of states, meanwhile in a broader sense, by world order BuLL means "those patterns or dispositions of human activity that sustain the elementary or primary goals of social life among mankind as a whole" 4

In this sense, it is at utmost relevant the idea that order among mankind as a whole is wider, more fundamental, more primordial and morally prior than order among states. ${ }^{5}$ The figure of state loses its primacy as we reach the concept of world order, and becomes a path for achieving global common values and interests.

Applying this idea to international economic order, there is an undeniable necessity to include other actors, new institutions and multiple dimensions to the classic analysis of economic international law, encompassing a broader view of the members of the economic community - possible by the lens of global economic governance.

On a similar perspective, JAmes Rosenau argues that, although with close relation to world order ${ }^{6}$ and

2 BULL, Hedley. The Anarchical Society: a study of order in world politics. 3. ed. Basingstoke; New York: Palgrave, 2002. p. 8.

3 BULL, Hedley. The Anarchical Society: a study of order in world politics. 3. ed. Basingstoke; New York: Palgrave, 2002. p. 11.

4 BULL, Hedley. The Anarchical Society: a study of order in world politics. 3. ed. Basingstoke; New York: Palgrave, 2002. p. 19.

5 BULL, Hedley. The Anarchical Society: a study of order in world politics. 3. ed. Basingstoke; New York: Palgrave, 2002. p. 21.

6 ROSENAU, James. Govenance without Government. In: ROSENAU, James; CZEMPIEAL, Ernst-Otto. Govenance, Order and Change in World Politics. Cambridge: Cambridge University Press, 1992. p. 1-29. Specially on the complex relation between order and governance, the author explicates that "In sum, governance and order are clearly interactive phenomena. As intentional activities designed to regularize the arrangements whicg sustain world affairs, governance obviously shapes the nature of the prevailing global order. It could not do so, if the patters constituting the order did not facilitate governanxe. Thus order is both a precondition and a consequence of government. Neither comes firts qand each helps explain the 
government, governance refers to a more encompassing phenomenon that embraces not only governmental institutions but also informal, non-governmental and sub-national mechanisms. Governance is an inter-subjective system of rules, with its construction, contents and application shared by multiple actors. ${ }^{7}$

At the same time, Mark ZaCHER points out that we are facing the fall of the Westhalian order's paradigm, and the rise of a new architecture of the global world. ${ }^{8}$ In a changing world order, states are becoming "increasingly enmeshed in a network of interdependencies and regulatory/ collaborative arrangements" ${ }^{\prime}$, and to this webs of commitments it may be added, as a recent novelty, the peoples acknowledgement of their common risks and future, recognizing each other increasingly as part of humankind. ${ }^{10}$

In this crisis of paradigm, institutions assume an essential role in global governance, as it becomes an attempt to conceive rules and mechanisms of management to regulate complex multi-dimensions situations. The importance of the institutions has not been unnoticed by the authors, that recognize it empirically ${ }^{11}$ and normatively. ${ }^{12}$ Institutions may be comprehended as expression of collaboration and exercising functions of global order in international society ${ }^{13}$, and have un-

othet. There can be no governance without order and there can be no order without governance (unless periods of disorder are regarded as forms of order)." p. 8 7 ROSENAU, James. Govenance without Government. In: ROSENAU, James; CZEMPIEAL, Ernst-Otto. Govenance, Order and Change in World Politics. Cambridge: Cambridge University Press, 1992. p. 1-29.

8 ZACHER, Mark. The Decaying pillars of the Westphalian temple: Implications for International Order and Governance. In: ROSENAU, James; CZEMPIEAL, Ernst-Otto. Governance, Order and Change in World Politics. Cambridge: University Press, 1992. p. 58-101.

9 ZACHER, Mark. The Decaying pillars of the Westphalian temple: Implications for International Order and Governance. In: ROSENAU, James; CZEMPIEAL, Ernst-Otto. Governance, Order and Change in World Politics. Cambridge: Cambridge University Press, 1992. p. 58-101. p. 60.

10 ZACHER, Mark. The Decaying pillars of the Westphalian temple: Implications for International Order and Governance. In: ROSENAU, James; CZEMPIEAL, Ernst-Otto. Governance, Order and Change in World Politics. Cambridge: University Press, 1992. p. 58-101. p. 111.

11 ROSENAU, James. Govenance without Government. In: ROSENAU, James; CZEMPIEAL, Ernst-Otto. Govenance, Order and Change in World Politics. Cambridge: Cambridge University Press, 1992. p. 1-29.

12 BULL, Hedley. The Anarchical Society: a study of order in world politics. 3. ed. Basingstoke; New York: Palgrave, 2002.

13 BULL, Hedley. The Anarchical Society: a study of order in world politics. 3. ed. Basingstoke; New York: Palgrave, 2002. p. 71. "Symbolize the existence of an international society that is more than the sum of its members, to give substance and performance to their deniable role in "governing globalization". ${ }^{14}$

In what regards to global economic governance, economic aspects of this increasingly enmeshed network caused by globalization urges for effective global governance, beyond formal structures that have been ineffective in developing and protecting the values and interests of stakeholders in the global economy. ${ }^{15}$

It is necessary, for this approach, to conceive international economic law and international normative phenomenon in a broader perspective, encompassing new protagonists and structures that were once only considered in international politics, understood before as a completely different and hermetic field, as we contend that national judges are essential pillars to global governance, as we will further develop.

\section{Disaggregation of the State and the Re- View of State Sovereignty: Necessity of a NEW PERSPECTIVE}

The reality brought by globalization in its multiple dimensions resulted in a rupture with the "dogma" of State's unity in international law ${ }^{16}$, triggering the disaggregation of the State as the initial platform for its analysis in world order. As ANDrew Hurrel emphasizes, this dominant perspective with liberal origins includes the novelty of giving ontological primacy to individuals and groups within the State, and comprises an increase of transnational relations that involve different parts of the state acting together with private actors,

collaboration in carrying out the political functions of international society".

14 MISTRAL, Jacques. Globalization Needs better Governance. Politique Étrangère, v. 5, p. 153-162, 2008. Available at: <http:// www.cairn.info/revue-politique-etrangere-2008-5-page-153.html>. Access on: 15 set. 2015.

15 BRADLOW, Daniel D. Framework For Assessing Global Economic Governance. Boston College Law Review, v. 54, n. 3, p. 971-1003, 2013.

16 Commenting the phenomenon of decay of the traditional concept of sovereignty in international law and the unity of state itself, Cf: FERRAJOLI, Luigi. A soberania no mundo moderno: nascimento e crise do Estado Nacional. São Paulo: M. Fontes, 2002. "Falar em 'Estados soberanos', se já não é aceito no plano da teoria do direito, também não o é no plano da teoria política. De fato, o que entrou irreversivelmente em crise, bem antes do atributo da soberania, é precisamente seu sujeito: o Estado nacional unitário e independente, cuja identidade, colocação e função precisam ser repensadas à luz da atual mudança, de fato e de direito, das relações internacionais.". 
and with bodies of other states. ${ }^{17}$

Hence, States cannot be conceived any longer as artificial units constructing its relations, but as an aggregate of elements, such as its legislative, executive and judicial branches, civil society, NGOs and firms that influence the formulation of global governance. Therefore, the same transformation forces that demands changes broadly in traditional international law have been remodeling States radically, demanding an urgent review on the definitions and consequences of sovereignty nowadays.

According to Anne Marie Slaughter, changes in the concept of sovereignty are necessary in view of the new reality of international society. The Westphalian sovereignty is no longer effective to explain the ambiguous role of States in the construction of the global order. Thus, there must take place a new interpretation of sovereignty, related to the ability to participate in international and transgovernmental regimes, networks and institutions increasingly necessary for the achievement of the goals of the global society. Therefore, the new sovereignty is related to the ability to participate in joint efforts, and to be in connection to the rest of the world. ${ }^{18}$

In fact, the transformation observed in the traditional idea of sovereignty is responding to changes in the international system and international relations, opening space for the performance of its institutions as architectures of global governance and reaffirming (this new type of) sovereignty. In other words,

\begin{abstract}
the state is no longer an interlocking set of government institutions in its domestic affairs, with sovereignty lodged in the people, and a unitary entity in its foreign relations, with sovereignty a fundamental attribute of its statehood. Instead, its internal and external face begin to mirror one another, as sovereignty becomes inextricably interwoven with accountability. ${ }^{19}$
\end{abstract}

A clear example of this scenario is the formation of governance networks in response to threats that also follow a logical increasingly rectified. ${ }^{20}$ Once the-

17 HURREL, Andrew. On Global Order: Power, Values and the Constitution of International Society. Oxford University Press, 2007. p. 115-116.

18 SLAUGHTER, Anne-Marie. Sovereignty and Power in a Networked World Order. Standford Journal of International Law, v. 40, p. 283-327, 2004.

19 HELFER, Laurence R; SLAUGHTER, Anne-Marie. Toward a Theory of Effective Supranational Adjudication. Yale Law Journal, v. 107, n. 2, p. 273-391, 1998. p. 388

20 SLAUGHTER, Anne-Marie. Sovereignty and Power in a Net- se governance networks share information, coordination and implementation efforts, beneficial effects are created for the world order. There is a movement of deterioration of the linking of state organs to traditional sovereignty, to domestic normativity and to national interests, as they start to be understood as institutions of global governance, linked to a relational sovereignty - owing respect to the global community.

As Andrew Hurrel suggests, "institutions, including state institutions, should not be seen as representatives of sovereign power or as embodiments of a particular community, but rather as functional bodies that compete with one another to provide efficient solutions to governance problems". ${ }^{21}$ National judges and tribunals are one of these institutions, that although needing to comply with legitimacy and accountability frameworks, must be conscious about its role in resolving governance demands.

In this perspective, in one hand there is an urgent necessity to encompass stakeholders of global economic governance in the administration of its dimensions, as the formal position of states in international forums searching for the development of solutions to problems in international economic order, may no longer be seen as representing the complex spectrum of its actors. On the other hand, national judges and courts may contribute as institutions for global economic governance. ${ }^{22}$

\section{Constitutional perspective to internatio- NAL LAW: TOWARDS A "COSMOPOLITAN LAW"}

With the "failure" of statehood paradigm, some perspectives have been developed to replace its gap

worked World Order. Standford Journal of International Law, v. 40, p. 283-327, 2004.

21 HURREL, Andrew. On Global Order: Power, Values and the Constitution of International Society. Oxford University Press, 2007. p. 115.

22 PETERSMANN, Ernst-Ulrich. Multi-Level Judicial Trade Governance without Justice? On the Role of Domestic Courts in the WTO Legal and Dispute Settlement System. European University Institute, Department of Law, EUI Working Paper LAW n. 2006/44. Available at: < http://cadmus.eui.eu/handle/1814/3/ browse? value $=$ PETERSMANN, + Ernst-Ulrich\&type $=$ author $>$. Access on: 15 set. 2015. p. 8; PETERSMANN, Ernst-Ulrich. The Future of the WTO: From Authoritarian Mercantilism to Multilevel Governance for the Benefit of Citizens. Asian Journal of WTO \& International Health Law and Policy, v. 6, n. 1, p. 45-80, mar. 2011. 
as a project for world order. ${ }^{23}$ In this context, we will briefly describe the perspective of constitutionalism and cosmopolitan law as a project for global order, and the layers of multilevel trade governance encompassing multilateral, regional and national levels of norms and institutions.

Albeit there are multiple different definitions, JÜRGEN Habermas presents the perspective of constitutionalization as directly connected to the Kantian cosmopolitan law "project", intended to transform international law as a law of states into cosmopolitan law of individuals. ${ }^{24}$ The conception of cosmopolitanism introduced by KANT is related to the idea of "public use of reason", and the notion of cosmopolitan right as an entitlement to dialogue and participate in cosmopolitan society. ${ }^{25}$

DAvid Held use this notion as background to defend a "layered cosmopolitan perspective" that lead to a cosmopolitan law embracing global, regional, national, and local forms of power and authority, centered on citizenships as human beings entitled to equal liberty and to multiple forms of governance founded on deliberation and consent. ${ }^{26}$

The idea of constitutionalization is used in the context of multilateral trading system in reference to (a) the WTO institutional architecture; (b) the process of judicial balance operated by WTO dispute settlement; and/or (c) the primacy of a set of normative commitments. ${ }^{27}$

23 Other main perspectives of analysis of contemporary international law, besides the perspective of constitutionalism, are (a) the fragmentation of international law and (b) the legal pluralism. For more details, Cf: KOSKENNIEMI, Martii. The Fate of Public International Law: Between Technique and Politics. Modern Law Review, v. 70, n. 1, p. 1-30, jan. 2007.

24 HABERMAS, Jürgen. Does the Constitutionalization of International Law Still Have a Chance? In: HABERMAS, Jürgen. The Divided West. Cambridge: Polity Press, 2006. p. 115-193. p. 115-124. 25 HELD, David. Principles of cosmopolitan order. Chaper 2. In: BROCK, Gillian; BRIGHOUSE, Harry. (Ed.) The Political Philosophy of Cosmopolitanism. Cambridge: Cambridge University Press, 2005. p. 18, 26, 27.

26 HELD, David. Principles of cosmopolitan order. Chaper 2. In: BROCK, Gillian; BRIGHOUSE, Harry. (Ed.) The Political Philosophy of Cosmopolitanism. Cambridge: Cambridge University Press, 2005. p. 10-27. p. 11.

27 DUNOFF, Jeffrey L. Why Constitutionalism Now? Text, Context and the Historical Contingency of Ideas. Journal of International Law and International Relations, v. 1, p. 191-211, 2005. In the first use of the idea: JACKSON, John. The Jurisprudence of GATT and the WTO. Cambridge: Cambridge University Press, 2000. In the second use of the idea: CASS, Deborah Z. "The "Constitutionali-
Therefore, choosing the multilateral trading system as a platform for reflecting about international economic order, is necessary to design a clear connection between the constitutional paradigm and the cosmopoli$\tan$ ideal $^{28}$, which is possible by the means of the layers of multilevel trade governance ${ }^{29}$, as an integration and interpenetration between national, regional and global institutions for constructing and applying international economic order. ${ }^{30}$

zation" of International Trade Law: Judicial Norm-Generation as the Engine of Constitutional Development in International Trade'. European Journal of International Law, v. 12, n. 1, p. 39-75, 2001. p. 42. In the third use of the idea: PETERSMANN, Ernst-Ulrich. How to Constitutionalize International Law and Foreign Policy for the Benefit of Civil Society? Michigan Journal of International Law, v. 20, p. 1-30, 1998. p. 13; PETERSMANN, Ernst-Ulrich. Human Rights, International Economic Law and Constitutional Justice: A Rejoinder. European Journal of International Law, v. 19, n. 5, p. 955-960, 2008. PETERSMANN, Ernst-Ulrich. Multilevel Judicial Governance as Guardian of the Constitutional Unity of International Economic Law. Loyola of Los Angeles International and Comparative Law Review, v. 30, n. 3, p. 367-418, 2008.

28 CHARNOVITZ, Steve. WTO Cosmopolitics. New York University Journal of International Law \& Politics, v. 34, p. 299-354, 2002. Arguing that WTO needs more "cosmopolitics," which the author defines as global political action transcending a strict state-to-state, or multilateral, basis."

29 SLAUGHTER, Anne-Marie. BURKE-WHITE, William. Future of International Law Is Domestic (or, the European Way of Law). Harvard International Law Journal, v. 47, p. 327-352, 2006. HSUEH, Ching-wen. Direct Effect, WTO Compliance Mechanism and the Protection for Individuals: Lessons Learned from the EC. Asian Journal of WTO \& International Health Law and Policy, v. 4, n. 2, p. 521-556, Sept. 2009. PETERSMANN, Ernst-Ulrich. From the Hobbesian International Law of Coexistence to Modern Integration Law: The WTO Dispute Settlement System. Journal of International Economic Law, v. 1, n. 2, p. 175-198, 1998. PETERSMANN, Ernst-Ulrich. Multilevel Judicial Governance as Guardian of the Constitutional Unity of International Economic Law. Loyola of Los Angeles International and Comparative Law Review, v. 30, n. 3, p. $367-$ 418, 2008. PETERSMANN, Ernst-Ulrich. The Future of the WTO: From Authoritarian Mercantilism to Multilevel Governance for the Benefit of Citizens. Asian Journal of WTO \& International Health Law and Policy, v. 6, n. 1, p. 45-80, mar. 2011.

30 Albeit with some conceptual differences, this perspective may be connected to the "global administrative law" KINGSBURY, Benedict; KRISCH, Nico. Introduction: Global Administrative Law. European Journal of International Law, v. 17, n. 1, p. 1-13, 2006. STEWART, Richard B.; BADIN, Michelle R. S. The World Trade Organization: multiple dimensions of global administrative law. International Journal of Constitutional law, v. 9, p. 556-586, 2011. and to the "multisystem of regulation of international trade" THORSTENSEN, Vera; PRADO, Victor Luiz. O Multissistema Da Regulação Do Comércio Global: Proposta De Novo Referencial Teórico e Nova Metodologia de Análise. In: BAPTISTA, Luiz Olavo; FERRAZ JUNIOR, Tercio Sampaio. Novos caminhos do século XXI: direito internacional, filosofia jurídica e política, dogmática jurídica e direitos fundamentais: uma homenagem a Celso Lafer. Curitiba: Juruá, 2013. 


\section{National Judges in this scenario}

International Courts and Tribunals have increasing relevance in global order, since they are institutionalized agents of interpretation and application of international law, beyond the primary will of states. Beyond the emergence of international courts and tribunals in the past decades ${ }^{31}$, it is possible to recognize in the international reality a phenomenon of "bybridization of the application of international law", which would indicate an increasing merger of domestic laws and its institutions - among them especially the judiciary- in the concretion of international law. ${ }^{32}$

Therefore, they may be placed as part of a system of multilevel global governance, "as part of a system of multilevel global governance in which the national and international levels are more deeply intertwined than ever before." ${ }^{33}$ Although often ignored in their role in the enforcement of international law, national courts are also vital elements of creating, implementing and enforcing international rules and dealing with global governance challenges.

It is relevant to revisit the theory of "role splitting" (dedoublement fonctionelle) created by GeOrges ScELle, which impacted on the work of many authors. Beyond the theories of monism and dualism, Georges SCELLE envisioned that the relationship between the spheres of domestic and international normativity should be understood by using the functional capacity of internal actors - among them the national judges - to ensure the effectiveness of the international order. ${ }^{34}$ That is, domestic courts integrates itself as part of international law, facing the organic lack of international law, without failing to perform their own competencies, and becoming thus (inter)national judges and courts.

In a scenario of spectacular organic development of the international system, accompanied by an expansion of density limits and rules of international law, in a ' $\mathrm{glo}$ balization of law ${ }^{35}$, the actuality of his theory is revea-

31 CHARNEY, Jonathan. Is International Law threatened by multiple international tribunals? Recueil des Cours. Collected Courses of the Hague Academy of International Law, v. 271, p. 101-382, 1998. p. 116.

32 BURKE-WHITE, William W. International Legal Pluralism. Michigan Journal of International Law, v. 25, p. 963-979, 2004. p. 975-7 33 BURKE-WHITE, William W. International Legal Pluralism. Michigan Journal of International Law, v. 25, p. 963-979, 2004. p. 977

34 SCELLE, Georges. Regle generales du droit de la paix. Recueil des cours de l'Academie de La Haye, v. 46, p. 327-696, 1933. p. 356-359

35 DUPUY, Pierre-Marie. Unité d'Application du Droit à led, since have been given increased opportunities for domestic courts to play a substantial role as means of safeguarding world order. ${ }^{36}$

From the perspective of Antonio Cassese, these opportunities come in two facets. First, in the case of treaties that expressly provide to the contracting parties the power to exercise jurisdiction with a vocation to universality, giving national courts the power to act as an organ of international society. Secondly, there are situations in which the need for action arises directly from national judges in the face of international inertia, subrogating itself as legitimate enforcers of international rules, in an attempt to replace the collective enforcement of international bodies and acting as true organs of the international society.

In another perspective, EyAL BENVENISTI and GEORGE W. Downs call attention to the changes and consequences of the current scenario in which are national judges and Courts. Given the jurisidicization, evidenced by the proliferation of international courts and tribunals and expansion of their reach, there is the increasing role of international judicial bodies on issues that come into the powers previously reserved to the domestic law. Thus, in this context the position of national courts would have changed "instinctively" or "strategically", once they discovered that the most efficient way to maintain their inner space of deliberation would be ensuring that their judgments are complementary rather than conflicting with other national and international decisions, leading them to a kind of "tacit coordination". ${ }^{37}$

YUVAL SHANY also recognizes the evolution of recent decades, in the increasing of participation of national courts in contributing to development of international law, although seeing its role as an activity increasingly more technical:

\begin{abstract}
a number of national courts have adopted a more international law friendly attitude and have started applying international law with greater frequency, in what appears to be a professional and credible manner (even in politically-charged cases involving their own governments). ${ }^{38}$
\end{abstract}

l'Echelle Globale et Responsabilité des Juges. European Journal of Legal Studies, v. 1, n. 2, p. 245-269, 2007.

36 CASSESE, Antonio. Remarks on Scelle's Theory of "Role Splitting" (dedoublement fonctionnel) in International Law. European Journal of International Law, v. 1, n. 1, p. 210-231, 1990. p. 228

37 BENVENISTI, Eyal; DOWNS, George W. National Courts, Domestic Democracy, and the Evolution of International Law. European Journal of International Law, v. 20, n. 1, p. 59-72, 2009. p. 61 38 SHANY, Yuval. No Longer a Weak Department of Power? Reflections on the Emergence of a New International Judiciary. Eu- 
Pierre-Marie Dupuy stress that this growing cooperation between the domestic and international courts is related to a gradual change in the self-perception of national judges about their participation in a larger totality, and their responsibilities as such. ${ }^{39}$ In this view, the responsibilities of the national courts, therefore, are not limited to cooperation with International Courts, nor to the factual and prevailing application of international norms to the facts presented to them internally, but to a shared sense of universal normativity and its axiological content. It presupposes, certainly, a substantial degree of knowledge of the international legal system by these agents, and an internal functional independence that enables them to exercise their "dual" role evidenced by Georges SCELle.

Defending a larger performance for domestic courts as deliverers of justice, ERnst-Ulrich Petersman also stress that the exercise of multilevel governance by national judges and courts at the legal dimension require a complex hermeneutical exercise, assuming their responsibility of fulfilling obligations present in international laconic texts, recognizing certain hierarchy in the international system -derived from erga omnes and jus cogens categories- and applying the principle of systemic interpretation erected by the Vienna Convention of the Law of Treaties. ${ }^{40}$

Beyond the legal dimension, Christopher WhytoCK aims to construct a methodology for assessing domestic courts participation in global governance by a systematic analysis of the global governance functions of domestic courts, on an interdisciplinary perspective. ${ }^{41}$ This "governance-oriented analysis", argues that domestic courts perform two global governance functions, first allocating governance authority, and second determining rights and obligations of transnational actors.

At one side, by allocating properly adjudicative, prescriptive, and enforcement authority, and on the other

ropean Journal of International Law, v. 20, n. 1, p. 73-91, 2009. p. 75-6 39 DUPUY, Pierre-Marie. Unité d'Application du Droit à l'Echelle Globale et Responsabilité des Juges. European Journal of Legal Studies, v. 1, n. 2, p. 245-269, 2007.

40 PETERSMANN, Ernst-Ulrich. Multi-Level Judicial Trade Governance without Justice? On the Role of Domestic Courts in the WTO Legal and Dispute Settlement System. European University Institute, Department of Law, EUI Working Paper LAW n. 2006/44. Available at: < http://cadmus.eui.eu/handle/1814/3/ browse? value $=$ PETERSMANN, + Ernst-Ulrich\&type $=$ author $>$. Acess on: 15 set. 2015. p. 8-9.

41 WHYTOCK, Christopher A. Domestic Courts and Global Governance. Tulane Law Review, v. 84, p. 67-124, 2010. side, by producing concrete decisions and delivering justice on transnational and global matters, domestic courts impact deeply not only on litigants, but also on global welfare. Ignoring its place in world order would be to ignore a potential force for properly addressing global challenges.

\section{WTO AND NATIONAL JUDJES: IS THERE A POS- SIBLE CONNECTION IN GLOBAL ECONOMIC GOVER- NANCE?}

Although there is no formal institutional linkage between the levels of judicial protection of global economic governance in international trade, ${ }^{42}$ we argue that national courts may contribute to the application of W'TO obligations, and especially to the concretization of the WTO Dispute Settlement decisions. ${ }^{43}$

As a general statement, there is no doubt that individuals may pursue existing rights in national court systems by legislation that implemented international rules. Although the distinction between direct and indirect applicability of international rules cannot be ignored, ${ }^{44}$ the question of guaranteeing effective legal protection of the rights and interests of the individual in the international trading system is a matter of crucial interest. ${ }^{45}$

Thus, as basic judicial protection of the individual is part of the rule of law, and is present not only in national but also international legal instruments, international economic matters may also be subject to national judicial analysis. In the European Union context, for example, there have been recognized a fundamental right to export or import, as derived from the freedom of profession, the right to equal treatment, the protec-

42 HILF, Meinhard. Role Of National Courts In International Trade Relations. Michigan Journal of International Law, v. 18, p. 321356, 1997.

43 PETERSMANN, Ernst-Ulrich. Multi-Level Judicial Trade Governance without Justice? On the Role of Domestic Courts in the WTO Legal and Dispute Settlement System. European University Institute, Department of Law, EUI Working Paper LAW n. 2006/44. Available at: < http://cadmus.eui.eu/handle/1814/3/ browse value $=$ PETERSMANN, + Ernst-Ulrich\&type $=$ author $>$. Acess on: 15 set. 2015. p. 18-19

44 ZHANG, Xin. Domestic Effect of the WTO Agreement in China: Trends and Implications. The Journal of World Investment,v. 3, p. $912-937,2002$. p. 321.

45 HILF, Meinhard. Role Of National Courts In International Trade Relations. Michigan Journal of International Law, v. 18, p. 321356, 1997. 
tion of property, and the freedom to pursue trade or business, which may be relevant to international trade. Accordingly, courts have derived a fundamental right to export or import in this context, although this right should be interpreted bearing in mind its social function and respecting a broad discretionary space to Community institutions. ${ }^{46} 47$

As mentioned above, national judges may play a double role, as they are not only enforcers of national law but may also be regarded as genuine enforcers of international instruments. This "deconcentrated enforcement" is a valid logic for economic global governance, and should be regarded less cautiously by the government of WTO members. ${ }^{48}$

As describes Meinhalf Hilf, this path would enhance the legitimacy of international trade rules and its compliance:

It is in the self-interest of the WTO and othe international organizations who set and apply international rules, that these rules be applied as effectively as possible to the grass-root relations of the individual operators. The more national courts become involved in the implementation of international rules, the more the relevant international institutions will gain domestic political support and thus, legitimacy. Only such support can guarantee effective implementation and faithful compliance in the long run. Such support is essential for the legitimization of new international rules. Accordingly, internationalism should have its firm roots at home. ${ }^{49}$

WTO Agreements are almost silent in what regards to the role of national courts in international trade dispute resolution. Nevertheless, specific clauses ${ }^{50}$ mention national judicial authorities, such as Article $\mathrm{X}$ of GATT ${ }^{51}$ and Articles 41 to 50 of TRIPS Agreement,

46 HILF, Meinhard. Role Of National Courts In International Trade Relations. Michigan Journal of International Law, v. 18, p. 321356, 1997. PETERSMANN, Ernst-Ulrich. Constitutional Functions and Constitutional Problems of International Economic Law, Progress and Undercurrents in Public International Law, v. 3, 1, 387 (1991). 47 Case C-280/93, Germany v. Council, 1994 E.C.R. 1-4973, 1-4974-78. Case 52/81, Faustv. Commission, 1982 E.C.R. 3745.

48 HILF, Meinhard. Role Of National Courts In International Trade Relations. Michigan Journal of International Law, v. 18, p. 321356, 1997.

49 HILF, Meinhard. Role Of National Courts In International Trade Relations. Michigan Journal of International Law, v. 18, p. 321356, 1997. p. 326.

50 Other examples are the Article 3 of the Antidumping Agreement, Article 23 of Subsidies Agreement and Article XX Agreement on Government Procurement.

51 Article X:3.(b). "[...] b) Each contracting party shall maintain,
${ }^{52}$ regarding enforcement of intellectual property rights,

or institute as soon as practicable, judicial, arbitral or administrative tribunals or procedures for the purpose, inter alia, of the prompt review and correction of administrative action relating to customs matters. Such tribunals or procedures shall be independent of the agencies entrusted with administrative enforcement and their decisions shall be implemented by, and shall govern the practice of, such agencies unless an appeal is lodged with a court or tribunal of superior jurisdiction within the time prescribed for appeals to be lodged by importers; Provided that the central administration of such agency may take steps to obtain a review of the matter in another proceeding if there is good cause to believe that the decision is inconsistent with established principles of law or the actual facts.". Available at: < https://www.wto.org/english/docs_e/ legal_e/gatt47_01_e.htm>.

52 Specially these clauses are relevant to the thesis: "Article 41. 1. Members shall ensure that enforcement procedures as specified in this Part are available under their law so as to permit effective action against any act of infringement of intellectual property rights covered by this Agreement, including expeditious remedies to prevent infringements and remedies which constitute a deterrent to further infringements. These procedures shall be applied in such a manner as to avoid the creation of barriers to legitimate trade and to provide for safeguards against their abuse. [...] 4. Parties to a proceeding shall have an opportunity for review by a judicial authority of final administrative decisions and, subject to jurisdictional provisions in a Member's law concerning the importance of a case, of at least the legal aspects of initial judicial decisions on the merits of a case. However, there shall be no obligation to provide an opportunity for review of acquittals in criminal cases. 5. It is understood that this Part does not create any obligation to put in place a judicial system for the enforcement of intellectual property rights distinct from that for the enforcement of law in general, nor does it affect the capacity of Members to enforce their law in general. Nothing in this Part creates any obligation with respect to the distribution of resources as between enforcement of intellectual property rights and the enforcement of law in general. Article 42 Fair and Equitable Procedures. Members shall make available to right holders civil judicial procedures concerning the enforcement of any intellectual property right covered by this Agreement. Defendants shall have the right to written notice which is timely and contains sufficient detail, including the basis of the claims. Parties shall be allowed to be represented by independent legal counsel, and procedures shall not impose overly burdensome requirements concerning mandatory personal appearances. All parties to such procedures shall be duly entitled to substantiate their claims and to present all relevant evidence. The procedure shall provide a means to identify and protect confidential information, unless this would be contrary to existing constitutional requirements. [...] Article 44. Injunctions 1.The judicial authorities shall bave the authority to order a party to desist from an infringement, inter alia to prevent the entry into the channels of commerce in their jurisdiction of imported goods that involve the infringement of an intellectual property right, immediately after customs clearance of such goods. Members are not obliged to accord such authority in respect of protected subject matter acquired or ordered by a person prior to knowing or having reasonable grounds to know that dealing in such subject matter would entail the infringement of an intellectual property right. [...] Article 45 Damages 1. The judicial authorities shall have the authority to order the infringer to pay the right holder damages adequate to compensate for the injury the right holder has suffered because of an infringement of that person's intellectual property right by an infringer who knowingly, or with reasonable grounds to know, engaged in infringing activity. [...] Article 46 Other Remedies. In order to create an effective deterrent to infringement, the judicial authorities shall bave the authority to order that goods that they have found to be infringing be, without compensation of any sort, disposed of outside the channels of commerce in such a manner as to avoid any harm caused to the right holder, or, unless this would be contrary to existing constitutional requirements, destroyed. The judicial authorities shall also have the authority to order that materials and implements 
providing for "expeditious remedies to prevent infringements and remedies which constitute a deterrent to further infringements". ${ }^{53}$

More importantly, W'TO members have a large space of discretion in how they may choose to respond to their obligations under its agreements and specially how they may choose to implement a decision from the WTO Dispute Settlement System, and thus judicial authorities are not ab initio excluded from implementation processes.

Since WTO Agreements do not have express reference to its applicability/ invocability in the legal systems of its members, it is commonly recognized that this definition has been left to each national legal system. ${ }^{54}{ }^{55}$ Notwithstanding WTO members have generally

the predominant use of which has been in the creation of the infringing goods be, without compensation of any sort, disposed of outside the channels of commerce in such a manner as to minimize the risks of further infringements. In considering such requests, the need for proportionality between the seriousness of the infringement and the remedies ordered as well as the interests of third parties shall be taken into account. In regard to counterfeit trademark goods, the simple removal of the trademark. unlawfully affixed shall not be sufficient, other than in exceptional cases, to permit release of the goods into the channels of commerce. PROVISIONAL MEASURES Back. Article 50 1. The judicial authorities shall have the authority to order prompt and effective provisional measures: (a) to prevent an infringement of any intellectual property right from occurring, and in particular to prevent the entry into the channels of commerce in their jurisdiction of goods, including imported goods immediately after customs clearance; (b) to preserve relevant evidence in regard to the alleged infringement. 2. The judicial authorities shall have the authority to adopt provisional measures inaudita altera parte where appropriate, in particular where any delay is likely to cause irreparable harm to the right holder, or where there is a demonstrable risk. of evidence being destroyed. [...]”. Available at: <https://www.wto.org/ english/tratop_e/trips_e/t_agm4_e.htm>.

53 Article 41.1. TRIPS Agreement. Available at: <https://www. wto.org/english/tratop_e/trips_e/t_agm4_e.htm>.

54 "[...] Como regra geral, o próprio efeito direto das normas da OMC dependerá da estrutura constitucional e do status concedidos aos tratados pela ordem jurídica de cada Membro. [...] Na OMC, entretanto, não há regras que gerem efeitos diretos, para a esfera normativa nacional dos Membros, das decisões do OSC ou das interpretacõoes eventualmente adotadas pelos painéis e pelo OAp." BARRAL, Welber. Solução de controvérsias na Organização Mundial do Comércio. Brasília: Fundação Alexandre de Gusmão, 2007. p. 70 .

55 Petersmann has a different view in this matter, stressing that from article $\mathrm{X}$ of GATT it is possible to extract the obligation to ensure access to national jurisdiction for violations of multilateral rules: "Even though WTO law provides for a multilevel legal and dispute settlement system protecting also individual 'access to justice' in domestic courts (cf. GATT Article X and numerous other WTO provisions), many governments limit their domestic legal and judicial accountability for harmful violations of their WTO obligations by insisting that domestic courts should not protect domestic citizens against violations of WTO obligations and WTO dispute settlement rulings to the detriment of adversely affected citizens seeking judicial remedies in domestic courts." PETERSMANN, Ernst-Ulrich. Multilevel Governance Problems of the World Trading System beyond the denied direct applicability/invocability of WTO agreements, ${ }^{56}$ some of the most influential members in international trade (US, EU/EC, Japan) sought to evade from their ordinary practice regarding the applicability of international treaties in order to deny direct effects to WTO Law on their courts. ${ }^{57}$

By way of illustration, the fact that other WTO members do not concede direct applicability/invocability was one of the arguments used by the European Court of Justice to deny these effects to WTO Agreements, and this line of reasoning tends to be used by other members. ${ }^{58}$ Thus, it builds up a tautological reasoning that leads to widening the trend of limiting the possibility of exercising legitimate rights by global economic stakeholders (consumers, importers, exporters, etc.) towards national judicial authorities.

WTO Conference at Bali 2013. Journal of International Economic Law, v. 17 , p. 233-270, 2014. p. 248.

56 "Indeed, it appears that among the countries that, as a matter of principle, deny direct effect to WTO Agreements are all the major trading members of the WTO, namely the US, the EU, Canada, Japan, China, and so on. And yet they represent roughly 70 to 75 per cent of world trade. Through this lens, the denial of direct effect to the WTO agreements becomes more massive. At the same time, this approach evidences that the reasons cannot be exclusively legal. It is all the more true that some of these WTO members, such as the EU, could, according to the structure of their legal systems, eas-ily accommodate direct effect, at least for some provisions of WTO law, meeting the usual substantive requirements for granting direct effect.” FABRI, Hélène Ruiz. Is There a Case - Legally and Politically - for Direct Effect of WTO Obligations? European Journal of International Law, v. 25, n. 1, p. 151-173, 2014. p. 155.

57 "However, it is necessary to explore the underlying rationale for the EC, the United states and Japan to reject the direct invocability of the WTO Agreement regardless of their traditions and the obvious advantages. There are three argument against direct effect. First, the recognition of direct effect will undermine the sovereignty enjoyed by the Member and, in particular, by the legislature. The United States is the typical example. Second, such recognition will deprive legislative and administrative bodies of political flexibility and make their actions more susceptible to challenges by private parties. The ECJ holds this position. Third, the nature and structure of the WTO Agreement are flexible and not mandatory or precise enough to confer rights on private parties. The EC and Japan take such a view. [...] In conclusion, the group of leading world trading entities deviate from their normal position and specifically deny the direct invocability of the WTO Agreements or adopt a more restrictive attitude toward their domestic application." ZHANG, Xin. Domestic Effect of the WTO Agreement in China: Trends and Implications. The Journal of World Investment, v. 3, p. 912-937, 2002. p. 923. 58 Portugal v. Council (Rec.1999, p.I-8395), Case C-149/96, 23 nov. 1999. para. 44. "Admittedly, the fact that the courts of one of the parties consider that some of the provisions of the agreement concluded by the Community are of direct application whereas the courts of the other party do not recognise such direct application is not in itself such as to constitute a lack of reciprocity in the implementation of the agreement (Kupferberg, paragraph 18)." 
Conceptually, one should not ignore the distinction between applicability/invocability conferred to certain international treaty in a given national order and the applicability/invocability awarded to decisions of an adjudicative system or body created by that treaty. While there may be a tendency to treat these instruments similarly, obligations under the WTO agreements and those arising from decisions of the WTO Dispute Settlement System have remarkably different nature, as states ERnst-Ulrich Petersman:

In addition to the "primary" international legal obligations of each WTO Member to implement its WTO obligations in good faith and "ensure the conformity of its laws, regulations and administrative procedures with its obligations as provided in the annexed Agreements" (Article XVI.4 WTO Agreement), the adoption of WTO panel and Appellate Body findings by the DSB entails "secondary" obligations.

- to "secure the withdrawal of the measures concerned if these are found to be inconsistent with the provisions of any of the covered agreements" (Article 3 DSU), either "immediately" or within "a reasonable period of time" (cf Article 21.3 DSU) depending, inter alia, on whether compliance with WTO law requires legislative, administrative or judicial measures;

- if WTO treaty benefits continue to be nullified after the end of the implementation period, to accept either "a mutually satisfactory adjustment

(Article 26.1 DSU), including voluntary compensation as a "temporary measure" pending "full implementation of a recommendation to bring a measure into conformity with the covered agreements" (Article 22.1 DSU), or "suspension of concessions or other obligations" as a remedy aimed at rebalancing reciprocal WTO rights and obligations and inducing compliance with WTO law. ${ }^{59}$

According to this line of interpretation, there is an “independent" obligation to comply with WTO Dispute Settlement decisions. In this context, we may recall three relevant characteristics of WTO Dispute Settle-

59 PETERSMANN, Ernst-Ulrich. Multi-Level Judicial Trade Governance without Justice? On the Role of Domestic Courts in the WTO Legal and Dispute Settlement System. European University Institute, Department of Law, EUI Working Paper LAW n. 2006/44. Available at: < http://cadmus.eui.eu/handle/1814/3/ browse ?value $=$ PETERSMANN, + Ernst - Ulrich $\&$ type $=$ author $>$. Acess on: 15 set. 2015. p. 15-16. ment decisions: (i) legality, ${ }^{60}$ (ii) bindingness ${ }^{61}$ and (iii) undeterminedness (open character of the commands of the decisions, which are undetermined but determinable). ${ }^{626364}$

Decisions of the WTO Dispute Settlement System are thus expressed as commands of results, by requiring that the measure recognized as in disconformity be brought in conformity to multilateral obligations. The choice of means by which the result expected is achieved is to be determined by the member, in its discretionary space.

60 "The decisions are binding, and bring about legal consequences; the mechanism, in sum, is an integral part of Public International Law, and orients itself by the due process of law, what is endowed with significance and relevance". TRINDADE, Antônio Augusto Cançado. International law for humankind: towards a new jus gentium (II). General course on public international law. Recueil des cours, v. 317, p. 9-312, 2005. p. 205.

61 "In my view, these clauses over whelmingly imply, in the light of the practices of GATT, that the legal effect of an adopted panel report is the international law obligation to perform the recommendation or to comply with the "rulings" of the panel or appellate report." JACKSON, John. International Law Status of WTO Dispute Settlement Reports: Obligation to Comply or Option to Buy Out? American Journal of International Law, v. 98, p. 109-125, 2004. p. 115.

62 "[...] while a panel may suggest ways of implementing its recommendation, the choice of means of implementation is decided, in the first instance, by the Member concerned" WTO. WTO. Panel Report, United States - Anti Dumping Measures on Stainless Steel Plate in Coils and Stainless Steel Sheet and Strip from Korea. WT/DS179/R, 22 dez. 2000. para. 8.8.

63 " $[\mathrm{T}]$ he choice of the method of implementation rests with the implementing Member. However, the implementing Member does not have an unfettered right to choose any method of implementation. Besides being consistent with the Member's WTO obligations, the chosen method must be such that it could be implemented within a reasonable period of time in accordance with guidelines contained in Article 21.3(c). Objectives that are extraneous to the recommendations and rulings of the DSB in the dispute concerned may not be included in the method if such inclusion were to prolong the implementation period. Above all, it is assumed that the implementing Member will act in "good faith" in the selection of the method that it deems most appropriate for implementation of the recommendations and rulings of the DSB." WTO. Award of the Arbitrator, European Communities - Export Subsidies on Sugar (Arbitration under Article 21.3(c) of the DSU). WT/DS265/33, WT/ DS266/33, WT/DS283/14, 28 out. 2005. para. 69.

64 "Although Members generally have discretion to determine their means of implementation, this discretion is not without bounds. Saying that selecting the means of implementing the recommendations and rulings of the DSB is the prerogative of the implementing member is not at all the same as saying that "anything goes". To declare otherwise would be to allow implementing Members the discretion also to pursue implementation measures that needlessly and unduly extend the reasonable period of time needed for implementation. And this would be contrary to the objective of Article 21.3 of the DSU." Award of the Arbitrator, European Communities - Customs Classification of Frozen Boneless Chicken Cuts (Arbitration under Article 21.3(c) of the DSU). WT/DS269/13, WT/DS286/15, 20 fev. 2006. para. 56 
With regard to national implementation mechanisms, these may involve the action of one or more branches of government. Although implementation measures with the participation of the judiciary are not common, they cannot be discarded from the systematic implementation of WTO members.

Thus, if the measures constituting violation of multilateral rules may emanate from organs of the three branches of government, ${ }^{65}{ }^{66}$ it is reasonable to assume that implementation may require measures from all these powers. ${ }^{67}$ For instance, in the case Brazil- Measures Affecting Imports of Retreaded Tyres, national judiciary had enrolled a relevant part in implementing the WTO Dispute Settlement ruling, and it was recognized by the arbitrator as a legitimate measure. ${ }^{68}$

65 " $[. .$.$] the United States, of course, carries responsibility for ac-$ tions of both the executive and legislative departments of government." WTO. Appellate Body Report, United States - Standards for Reformulated and Conventional Gasoline. WT/DS2/AB/R, 29 abr. 1996. p. 28.

66 "The United States, like all other Members of the WTO and of the general community of states, bears responsibility for acts of all its departments of government, including its judiciary." WTO. Appellate Body Report, United States - Import Prohibition of Certain Shrimp and Shrimp Products. WT/DS58/AB/R, 22 out. 2001. para. 173.

67 "We note that a WTO Member "bears responsibility for acts of all its departments of government, including its judiciary." This is supported by Article 18.4 of the Anti-Dumping Agreement, Article XVI:4 of the WTO Agreement, and Article 27 of the Vienna Convention, The judiciary is a state organ and even if an act or omission derives from a WTO Member's judiciary, it is nevertheless still attributable to that WTO Member. Thus, the United States cannot seek to avoid the obligation to comply with the DSB's recommendations and rulings within the reasonable period of time, by relying on the timing of liquidation being "controlled by the independent judiciary.” WTO. Appellate Body Report, United States - Measures Relating to Zeroing and Sunset Reviews (Recourse to Article 21.5 of the DSU by Japan). WT/DS322/AB/RW, 29 ago. 2008. para. 182.

68 "In previous arbitrations, implementing Members have usually proposed either legislative or regulatory means to implement DSB recommendations and rulings. However, I do not consider that implementation through the judiciary can be a priori excluded from the range of permissible action that can be taken to implement DSB recommendations and rulings and bring about compliance with a Member's obligations under the covered agreements. The degree of government control may well be different with respect to the executive, the legislative, and the judiciary branches of power. Implementation action, whether it is taken by the legislature, or the judiciary, may not be executed in the way envisaged by the government. Yet the possibility of failure to achieve the intended compliance has not been regarded by previous arbitrators as a reason to question the permissibility of implementation by means of legislation, nor, in my view, does it exclude judicial action from the range of a permissible means of implementation. [...]" WTO. Brazil - Measures Affecting Imports of Retreated Tyres (Arbitration under Article 21.3(c) of the Understanding on Rules and Procedures Governing the Settlement
Last but not least, ERnST-Ulrich Petersman contends that a different approach of the matter by governments, improving the potential of its national courts in ruling disputes regarding certain private rights, by means of establishing effective remedies in WTO related matters, could prevent WTO disputes, reducing transaction costs and enhancing the rule of law. ${ }^{69}$

While facing certain skepticism, there is no legal impossibility or formal obstacle to enhancing the role of national judges in economic global governance, although this requires a consciousness of their responsibilities as such. However, as we conceive national judges and courts like institutions for global economic governance, many theoretical and practical questions arise. It is not our intention to answer or to exhaust the enumeration of these questions on this opportunity, but we contend that future reflections shall be constructed from the dimensions of (a) knowledge, (b) legitimacy and (c) accountability.

\section{Final Considerations: Callenges ahead}

Throughout this paper we developed the thesis that there is room and need for active participation of national judiciary authorities as institutions of global economic governance. Transformations in the architecture of the global world order has brought the necessity to consider rules, norms and institutions that lies beyond the state, and rethink about the management of change within international legal and normative structure of global order.

Applying this idea to international economic order, it is recognizable the necessity to include other actors, new institutions and multiple dimensions to the classic analysis of economic international law, encompassing a broader view of the members of the economic community - possible by the lens of global economic governance.

of Disputes). WT/DS332/16, 29 ago. 2008. para 68.DS332: Brazil - Measures Affecting Imports of Retreaded Tyres (Complainant: European Communities)

69 PETERSMANN, Ernst-Ulrich. Multi-Level Judicial Trade Governance without Justice? On the Role of Domestic Courts in the WTO Legal and Dispute Settlement System. European University Institute, Department of Law, EUI Working Paper LAW n. 2006/44. Available at: < http://cadmus.eui.eu/handle/1814/3/ browse ?value $=$ PETERSMANN, + Ernst-Ulrich\&type $=$ author $>$. Acess on: 15 set. 2015. p. 19. 
Regarding judicial structures, in this new paradigm, there is a movement of deterioration of the linking of state organs to traditional sovereignty, to domestic normativity and to national interests, as they start to be understood as institutions of global governance, linked to a relational sovereignty - owing respect to the global community.

In exercising their double role, as part of national apparatus and as part of global architecture, domestic judges must be aware of their "responsibility" towards other subjects beyond its national boundaries, and must properly have knowledge on the international legal system. This task brings implicit challenges, in the process of dominating international economic law and "language" without falling into the technicism and in the development of abilities to translate it in local, national and regional levels.

In dealing with legitimacy, many preoccupations arise in the ways of connecting institutions to citizens. National courts primarily earn its authority from States, but once comprehended as part of world order, they shall conquer its respect and authority from citizens and stakeholders of international economic community.

It is relevant in this matter the use of procedural mechanisms such as amicus curiae and public sessions in which judges have contact with underrepresented interests and points of view. It may also be necessary to discuss the processes of choosing these judges, as although representing a functional authority, they cannot always rupture with potential influences of their personal, philosophical and political background in exercising their power.

Last but not least, regarding the third dimension it is necessary to discuss the connections between national courts and the global public sphere, in which stakeholders shall be able to get involved on an ongoing process of accountability. Mechanisms of participation, transparency, evaluation and complaint need to be explored, as bridges between the performance of national courts and the global economic order.

As the thesis developed in the paper is an attempt to overcome the perspective of classic international law that erects a wall of separation between international order and domestic order, it aims to contribute to a new perspective for international law as a broader instrument for global governance. International economic law, although with distinct features and exactly be- cause it covers a variety of stakeholders having a broad spectrum of interests, should not be excluded from this perspective of multilevel global governance.

\section{References}

BENVENISTI, Eyal; DOWNS, George W. National Courts, Domestic Democracy, and the Evolution of International Law. European Journal of International Law, v. 20, n. 1, p. 59-72, 2009.

BARRAL, Welber. Solução de controvérsias na Organização Mundial do Comércio. Brasília: Fundação Alexandre de Gusmão, 2007.

BRADLOW, Daniel D. Framework For Assessing Global Economic Governance. Boston College Law Review, v. 54, n. 3, p. 971-1003, 2013.

BUERGENTHAL, Thomas. Self-executing and nonself-executing treaties in national and international law. Recueil des cours, v. 235, p. 303-400, 1992.

BULL, Hedley. The Anarchical Society: a study of order in world politics. 3. ed. Basingstoke; New York: Palgrave, , 2002.

BURKE-WHITE, William W. International Legal Pluralism. Michigan Journal of International Law, v. 25, p. $963-$ 979, 2004.

CASS, Deborah Z. "The "Constitutionalization" of International Trade Law: Judicial Norm-Generation as the Engine of Constitutional Development in International Trade'. European Journal of International Law, v. 12, n. 1, p. 39-75, 2001.

CASSESE, Antonio. Remarks on Scelle's Theory of "Role Splitting" (dedoublement fonctionnel) in International Law. European Journal of International Law, v. 1, n. 1, p. 210-231, 1990.

CHARNEY, Jonathan. Is International Law threatened by multiple international tribunals? Recueil des Cours. Collected Courses of the Hague Academy of International Law, v. 271, p. 101-382, 1998.

CHARNOVITZ, Steve. WTO Cosmopolitics. New York University Journal of International Law \& Politics, v. 34, p. 299-354, 2002.

DUNOFF, Jeffrey L. Why Constitutionalism Now? Text, Context and the Historical Contingency of Ideas. 
Journal of International Law and International Relations,v. 1, p. 191-211, 2005.

DUPUY, Pierre-Marie. Unité d'Application du Droit à 1'Echelle Globale et Responsabilité des Juges. European Journal of Legal Studies, v. 1, n. 2, p. 245-269, 2007.

FABRI, Hélène Ruiz. Is There a Case - Legally and Politically - for Direct Effect of WTO Obligations? European Journal of International Law, v. 25, n. 1, p. 151-173, 2014.

FERRAJOLI, Luigi. A soberania no mundo moderno: nascimento e crise do Estado Nacional. São Paulo: M. Fontes, 2002.

HABERMAS, Jürgen. Does the Constitutionalization of International Law Still Have a Chance? In: HABERMAS, Jürgen. The Divided West. Cambridge: Polity Press, 2006. p. 115-193.

HELD, David. Principles of cosmopolitan order. Chaper 2. In: BROCK, Gillian; BRIGHOUSE, Harry. (Ed.) The Political Philosophy of Cosmopolitanism. Cambridge: Cambridge University Press, 2005. p. 10-27.

HELFER, Laurence R; SLAUGHTER, Anne-Marie. Toward a Theory of Effective Supranational Adjudication. Yale Law Journal, v. 107, n. 2, p. 273-391, 1998.

HILF, Meinhard. Role Of National Courts In International Trade Relations. Michigan Journal of International Law, v. 18, p. 321-356, 1997.

HURREL, Andrew. On Global Order: Power, Values and the Constitution of International Society. Oxford University Press, 2007.

HSUEH, Ching-wen. Direct Effect, WTO Compliance Mechanism and the Protection for Individuals: Lessons Learned from the EC. Asian Journal of WTO \& International Health Law and Policy, v. 4, n. 2, p. 521-556, Sept. 2009.

JACKSON, John. International Law Status of WTO Dispute Settlement Reports: Obligation to Comply or Option to Buy Out? American Journal of International Law, v. 98, p. 109-125, 2004.

JACKSON, John. The Jurisprudence of GATT and the WTO. Cambridge: Cambridge University Press, 2000.

KINGSBURY, Benedict; KRISCH, Nico. Introduction: Global Administrative Law. European Journal of International Law, v. 17, n.1, p. 1-13, 2006.
KOSKENNIEMI, Martii. The Fate of Public International Law: Between Technique and Politics. Modern Law Review, v. 70, n. 1, p. 1-30, Jan. 2007.

MISTRAL, Jacques. Globalization Needs better Governance. Politique Étrangère, v. 5, p. 153-162, 2008. Available at: <http://www.cairn.info/revue-politique-etrangere-2008-5-page-153.html>. Access on: 15 set. 2015.

PETERSMANN, Ernst-Ulrich. From the Hobbesian International Law of Coexistence to Modern Integration Law: The WTO Dispute Settlement System. Journal of International Economic Law, v. 1, n. 2, p. 175-198, 1998.

PETERSMANN, Ernst-Ulrich. How to Constitutionalize International Law and Foreign Policy for the Benefit of Civil Society? Michigan Journal of International Law, v. 20, p. 1-30, 1998.

PETERSMANN, Ernst-Ulrich. Human Rights, International Economic Law and Constitutional Justice: A Rejoinder. European Journal of International Law, v. 19, n. 5, p. 955-960, 2008.

PETERSMANN, Ernst-Ulrich. Multilevel Governance Problems of the World Trading System beyond the WTO Conference at Bali 2013. Journal of International Economic Law, v. 17, p. 233-270, 2014.

PETERSMANN, Ernst-Ulrich. Multilevel Judicial Governance as Guardian of the Constitutional Unity of International Economic Law. Loyola of Los Angeles International and Comparative Law Review, v. 30, n. 3, p. 367 418, 2008.

PETERSMANN, Ernst-Ulrich. Multi-Level Judicial Trade Governance without Justice? On the Role of Domestic Courts in the WTO Legal and Dispute Settlement System. European University Institute, Department of Law, EUI Working Paper LAW n. 2006/44. Available at: < http://cadmus.eui.eu/handle/1814/3/ browse? value $=$ PETERSMANN, + Ernst Ulrich\&type $=$ author $>$. Acess on: 15 set. 2015.

PETERSMANN, Ernst-Ulrich. The Future of the WTO: From Authoritarian Mercantilism to Multilevel Governance for the Benefit of Citizens. Asian Journal of WTO \& International Health Law and Policy, v. 6, n. 1, p. 45-80, mar. 2011.

ROSENAU, James. Govenance without Government. In: ROSENAU, James; CZEMPIEAL, Ernst-Otto. Govenance, Order and Change in World Politics. Ambridge: Cambridge University Press, 1992. p. 1-29. 
SCELLE, Georges. Regle generales du droit de la paix. Recueil des cours de l'Academie de La Haye, v. 46, p. 327-696, 1933.

SHANY, Yuval. No Longer a Weak Department of Power? Reflections on the Emergence of a New International Judiciary. European Journal of International Law, v. 20, n. 1, p. 73-91, 2009.

SLAUGHTER, Anne-Marie. Sovereignty and Power in a Networked World Order. Standford Journal of International Law, v. 40, p. 283-327, 2004.

SLAUGHTER, Anne-Marie. BURKE-WHITE, William. Future of International Law Is Domestic (or, the European Way of Law). Harvard International Law Journal, v. 47, p. 327-352, 2006.

STEWART, Richard B.; BADIN, Michelle R. S. The World Trade Organization: multiple dimensions of global administrative law. International Journal of Constitutional law, v. 9, p. 556-586, 2011.

THORSTENSEN, Vera; PRADO, Victor Luiz. O Multissistema Da Regulação Do Comércio Global: Propo- sta De Novo Referencial Teórico e Nova Metodologia de Análise. In: BAPTISTA, Luiz Olavo; FERRAZ JUNIOR, Tercio Sampaio. Novos caminhos do século XXI: direito internacional, filosofia jurídica e política, dogmática jurídica e direitos fundamentais: uma homenagem a Celso Lafer. Curitiba: Juruá, 2013.

TRINDADE, Antônio Augusto Cançado. International law for humankind: towards a new jus gentium (II). General course on public international law. Recueil des cours, v. 317, p. 9-312, 2005.

WHYTOCK, Christopher A. Domestic Courts and Global Governance. Tulane Law Review, v. 84, p. 67-124, 2010.

ZACHER, Mark. The Decaying pillars of the Westphalian temple: Implications for International Order and Governance. In: ROSENAU, James; CZEMPIEAL, Ernst-Otto. Governance, Order and Change in World Politics. Cambridge: University Press, 1992. p. 58-101.

ZHANG, Xin. Domestic Effect of the WTO Agreement in China: Trends and Implications. The Journal of World Investment, v. 3, p. 912-937, 2002. p. 923. 
Para publicar na Revista de Direito Internacional, acesse o endereço eletrônico www.rdi.uniceub.br ou www.brazilianjournal.org.

Observe as normas de publicação, para facilitar e agilizar o trabalho de edição. 